\title{
DRINKING AND HEDONIC BEHAVIOR OF ALCOHOLIZED RATS
}

\author{
${ }^{1}$ Panova T.I. https://orcid.org/0000-0002-0298-802X \\ ${ }^{2}$ Bortnikova A.K. https://orcid.org/0000-0003-2145-6907 \\ ${ }^{1}$ Myronenko O.I. https://orcid.org/0000-0001-5221-7218 \\ Bogomolets National Medical University, Ukraine \\ Maxim Gorky Donetsk National Medical University, Ukraine
}

panova10000@gmail.com

Relevance. To relieve alcohol withdrawal syndrome, intravenous infusion of glucose and antidotes to neutralize ketone bodies are used. But after treatment, the craving for alcohol remains, and relapses of alcohol consumption are observed in $60-90 \%$ of patients. It remains unclear if there is a connection between hypoglycemia, ketosis, on the one hand, and the craving for alcohol consumption, on the other hand.

Objective: to find out the effect of glycemic level normalization and prolonged maintenance of normal blood glucose concentration on ethanol consumption in alcoholized rats. At the same time, we have chosen two alternative ways to eliminate hypoglycemia: 1) by providing animals with unlimited access to a water trough filled with glucose solution; 2) by forced feeding of animals with a high-carbohydrate diet.

Materials and methods. 70 rats were housed in the individual cages. First, two water troughs were placed in each cage for one week: first one was filled with pure water and another one contained $5 \%$ glucose solution. Second, forced alcoholization of rats was performed by leaving one trough filled with 10\% ethanol solution in each cage. Duration of alcoholization was different: 3 weeks for the 1st group of rats $(n=20), 6$ weeks for the 2 nd group of animals $(n=20)$, and 16 weeks for the 3 rd group of rats $(n=20)$. Animals of the control group $(n=10)$ received pure water. Third, after forced alcoholization, animals of the experimental groups had a free access to three different troughs for three weeks: the first trough was filled with pure water, the second one - with $5 \%$ glucose solution, and the third one contained $10 \%$ ethanol solution. Rats of the control group were able to choose between water and 5\% glucose solution. At the third stage, animals of the experimental groups were divided into two subgroups with 10 rats in each one. Animals of one of the subgroups from each experimental group were kept on high-carbohydrate diet: they were administered $1 \mathrm{ml} \mathrm{of} 40 \%$ starch kissel $(2.0 \mathrm{~g} / \mathrm{kg}$, in terms of glucose) per os 3 times a day. The volumes of all consumed fluids were recorded daily throughout the experiment. The results were processed using the MedStat program.

Results. Healthy rats drank $2.5 \pm 0.6 \mathrm{ml}$ of water and $1.6 \pm 0.6 \mathrm{ml}$ of glucose solution per $100 \mathrm{~g}$ of body weight daily. In the first 7 days of forced alcoholization, the animals drank $3.1 \pm 0.7 \mathrm{ml}$ of ethanol solution per $100 \mathrm{~g}$ of body weight. By the end of the third week, consumption of ethanol solution increased up to $4.9 \pm 0.8 \mathrm{ml}$ per $100 \mathrm{~g}$ of body weight $(\mathrm{p}<0.001)$, which indicated development of adaptation. By the end of the sixth week, there was a prominent elevation of ethanol consumption up to $6.4 \pm 0.9 \mathrm{ml}$ per $100 \mathrm{~g}$ of body weight, and the total volume of consumed alcohol solutions was 1.3 times higher than that of the third week $(\mathrm{p}<0.001)$. At the sixth week of observation, alcohol intake reached its climax, since further alcoholization up to 16 weeks did not lead to any changes in drinking behavior $(p=0.712)$. We consider that the minimal duration of forced alcoholization is 6 weeks. During the process of alcoholization, the total daily consumption of fluids by animals was increasing, compared to healthy rats, and, by the end of the 16th week, it exceeded the indicator of healthy rats by 1.8 times. In alcoholized rats, glucose loses its hedonic properties. By the end of the 16th week of alcoholization, under condition of free choice of drinks, glucose consumption was 8 times lower than that of in healthy animals. Rats consumed less ethanol if they were receiving additional high-carbohydrate diet. The duration of metabolic correction with a starch solution is important: the longer it is, the less alcohol craving will be.

Conclusions. Alcohol-dependent rats reject the glucose solution offered as a drink. But prolonged and forced administration of glucose leads to a decrease in alcohol consumption.

Keywords: alcoholized rats, hypoglycemia, loss of hedonic properties of glucose, forced correction of glycemia.

Relevance. Alcoholism is characterized by hypoglycemia, which develops because of inhibition of gluconeogenesis in the liver. The metabolism of brain cells is rearranged to utilize ketone bodies, which are excessively produced from acetyl-CoA in the liver. Ketone bodies are high-energy fuel molecules. Oxidation of one molecule of beta-hydroxybutyrate results in generation of 26 ATP molecules. The initiation of ketone bodies production occurs due to the shift of the NADPH/NADP ratio towards the excess of NADPH. In turn, the shift towards NADPH accumulation is the re- sult of the increased activity of alcohol dehydrogenase in the presence of high concentration of ethanol. Therefore, alcoholic ketosis is considered to be an adaptive response to hypoglycemia. [1, 5, 9, 14]. Alcohol ketosis is suspected to occur significantly more often than it is diagnosed $[1,5,9,14]$. In studies on alcoholized rats, we also recorded pronounced ketosis [10].

However, when ketosis reaches high levels, it turns from a useful adaptive reaction into pathological one. In high concentration, ketone bodies have a number of negative effects: metabolic acidosis, up to 
decompensated stage; high osmotic activity, leading to tissue dehydration; decreased oxygen binding by hemoglobin; ionization of functional groups of blood plasma proteins, leading to changes of their conformation and function; neurotoxicity (nausea, vomiting, malaise, headache) $[5,11]$. Therefore, antidotes that neutralize ketone bodies are used in the treatment of alcohol withdrawal syndrome $[3,11]$. At the same time, it is noted that suppression of ketosis is impossible to reach by a single administration of the antidote. That is why, to achieve a satisfactory effect, therapeutic regimens include two- and threeweek courses. Simultaneously, intravenous glucose infusion is used to improve brain nutrition $[3,11]$. Nevertheless, after the end of treatment, relapses of alcohol consumption are observed in $60-90 \%$ of patients, according to various sources $[2,6,12]$. This suggests a link between hypoglycemia, ketosis, on the one hand, and craving for alcohol consumption, on the other hand.

Objective: to find out how the elimination of hypoglycemia and long-term maintenance of normal glycemic level will affect the craving for ethanol consumption in alcohol-dependent rats.

At the same time, we have chosen two alternative ways to eliminate hypoglycemia: 1) by providing animals with unlimited access to a water trough filled with glucose solution; 2) by forced administration of starch per os.

\section{MATERIALS AND METHODS}

The experiment was carried out on 70 rats of both sexes weighing 200-350 g. The animals were kept in a vivarium with forced ventilation in the autumn-winter period. The temperature was maintained at the level of $18-22{ }^{\circ} \mathrm{C}$, which excluded excessive thirst. Rats were housed in the individual cages with free access to food. Food composition was given a lot of attention and kept constant in order to achieve a stable drinking behavior without provoking an excessive thirst for salty food or, conversely, refusal to drink due to the consumption of large amount of juicy fruits and vegetables.

The experiment was performed in three stages. However, access to drinking was not always the same.

At the first stage, two water troughs were placed in each cage for one week. The first troughs were filled with pure water and another one contained $5 \%$ glucose solution, so the rats had a free choice of drinking. The volume of drunk fluid from each trough was recorded daily. In this way, the hedonic properties of glucose were determined for each animal. Measurement accuracy was $0.5 \mathrm{ml}$ (graduation scale on the trough was $0.5 \mathrm{ml}$ ).

Then, at the second stage, forced alcoholization was carried out for several weeks: there was only one trough with $10 \%$ ethanol solution in each cage. Duration of alcoholization was different: 3 weeks for the 1st group of rats $(n=20), 6$ weeks for the 2 nd group of animals $(n=20)$, and 16 weeks for the 3 rd group of rats $(n=20)$. Animals of the control group $(n=10)$ received pure water.

At the third stage, after the end of the specified period of forced alcoholization, the animals of the experimental groups had a free access to three different troughs for three weeks: the first trough was filled with pure water, the second one contained $5 \%$ glucose solution, and the third one had $10 \%$ ethanol solution inside. The criterion for the formed alcohol addiction was the preference for ethanol. Since the animals differed in weight, the volume of drunk liquids was calculated per $100 \mathrm{~g}$ of body weight. Rats of the control group had a choice between pure water and 5\% glucose throughout these three weeks.

In addition, at the third stage of the experiment, each of the experimental groups was divided into two subgroups with 10 animals in each one. All rats were injected with $1.0 \mathrm{ml}$ of liquid per os three times a day, with an interval of 5 hours, from a syringe without a needle. Animals of the first subgroups received $0.9 \%$ sodium chloride, and the animals of the second subgroups were given $40 \%$ boiled starch kissel $(2.0 \mathrm{~g} / \mathrm{kg}$, in terms of glucose). The choice of starch was determined by the properties of this complex polysaccharide with a branched chain. It is broken down in the gastrointestinal tract for a long time, and the formed glucose is absorbed gradually, which ensures the maintenance of a stable level of glucose in the blood for a long period and does not provoke an overload to the insular apparatus.

The experimental results were processed using the MedStat program.

Since the distribution of the values of drunk liquid volumes did not differ from the normal one, parametric methods of statistical analysis were used. To present the data in the work, the average value of the drunk liquid volume $\boldsymbol{X}(\mathrm{ml} / 100 \mathrm{~g})$ and the standard deviation $\mathrm{s}(\mathrm{ml} / 100 \mathrm{~g})$ are given.

In the analysis of variance, multiple comparisons were performed using the Scheffe's test to determine the differences in means between groups and inside each group at different periods of time. Paired comparisons of the means in the samples were carried out using the Student's test, and comparisons with the control group were performed using the Dunnett's test.

During the experiments, we followed all the regulations and principles approved by the Decree of the First National Congress on Bioethics (Kyiv, 2001); by the Law of Ukraine No. 3447-IV "About protection of animals from cruel treatment" (February 21, 2006), with amendments No. 1759-VI (December 15, 2009); by the European Convention for the Protection of Vertebrate Animals used for Scientific and Other Purposes (Strasbourg, 1986). 


\section{RESULTS AND DISCUSSION}

Before the start of the experiment, rats drank, on average, $2.5 \pm 0.6 \mathrm{ml}$ of pure water per $100 \mathrm{~g}$ of body weight daily. For each animal, the range between the minimal and maximal volumes of water consumption was less than $2.3 \mathrm{ml}$ per $100 \mathrm{~g}$ of body weight, which indicated a stable drinking behavior determined by the balanced diet. In addition, the animals drank $1.6 \pm 0.6 \mathrm{ml}$ of glucose solution per $100 \mathrm{~g}$ of body weight daily. It has to be emphasized that the animals consumed the glucose solution when there was an excess of pure water in the cage. This indicates the hedonic properties of glucose. The total volume of drunk liquid averaged $3.9 \pm 1.1 \mathrm{ml}$ per $100 \mathrm{~g}$ of animal weight. The data of the drinking regimen in rats before alcoholization and by the end of forced alcoholization periods is presented in Table 1 .

The ethanol consumption during forced alcoholization was as follows. In the first seven days, the animals drank, on average, $3.1 \pm 0.7 \mathrm{ml}$ of ethanol solution per $100 \mathrm{~g}$ of body weight. We consider that the slight decrease in the total amount of drunk liquid can be explained by the unpleasant taste of ethanol for rats (before alcoholization, it was $3.9 \pm 1.1 \mathrm{ml}$ of pure water and glucose solution per $100 \mathrm{~g}$ of body weight).

According to the results shown in Table 1, further analysis of the drinking regimen of rats suggested that changes in cell metabolism were accumulating not in linear, but abrupt manner during alcoholization. Our observations showed that this elevation approximately occurred at the third and sixth weeks of alcoholization, because the most significant changes in drinking behavior were noted during these particular periods (according to the volume of consumed ethanol and glucose solutions).
By the end of the third week, the volume of consumed ethanol solution increased up to $4.9 \pm 0.8 \mathrm{ml}$ per $100 \mathrm{~g}$ of body weight $(\mathrm{p}<0.001)$, which probably indicated development of adaptation.

By the end of the sixth week, there was another peak in the consumption of ethanol solution: up to $6.4 \pm 0.9 \mathrm{ml}$ per $100 \mathrm{~g}$ of animal weight. On average, the volume of drunk liquids increased by 1.3 times $(p<0.001)$, compared with the indicator of the third week.

At the same time, during the experiment, it was noted that alcohol intake reached its climax, since further alcoholization up to 16 weeks did not lead to any principal changes in drinking behavior. When comparing the average volumes of ethanol solution drunk by rats from week to week, up to the sixteenth week of observation, the level of alcohol consumption remained stable. And when comparing the volumes of alcohol consumed at the end of the sixth and sixteenth weeks, no statistically significant differences were found $(p=0.712$ ). The stable consumption of ethanol solution during this period indicated the formed alcohol adaptation/preference/addiction.

Our attention was drawn to the fact of timedependent manner in climax formation of alcohol consumption. It happened by the end of the sixth week of forced alcoholization. In our opinion, this can be the rationale for the minimal time period required for forced alcoholization development. Changes in the consumption of ethanol and glucose solutions during forced alcoholization are shown in Figure 1, A.

During the process of alcoholization, the daily total consumption of liquids by rats was increasing, compared to healthy rats. By the end of the sixteenth week, it exceeded the parameter of healthy animals by 1.8 times (Fig. 2, B). The increased thirst was probably caused by the osmotic properties of ethanol and its metabolite, acetaldehyde.

The volume of consumed liquids in condition of free choice and at different periods of forced alcoholization of rats

\begin{tabular}{|c|c|c|c|c|}
\hline \multirow{2}{*}{ Group of animals } & \multicolumn{4}{|c|}{ The volume of drunk liquid, ml } \\
\hline & Pure water & $\begin{array}{l}5 \% \text { glucose } \\
\text { solution }\end{array}$ & $\begin{array}{l}10 \% \text { ethanol } \\
\text { solution }\end{array}$ & Total volume \\
\hline Healthy rats before alcoholization $(n=70)$ & $2.5 \pm 0.6$ & $1.6 \pm 0.6$ & - & $3.9 \pm 1.1$ \\
\hline $\begin{array}{l}\text { The1st experimental group }(\mathrm{n}=20) \text {, alcoholization } \\
\text { for } 3 \text { weeks }\end{array}$ & $0.7 \pm 0.6^{*}$ & $1.1 \pm 0.4^{*}$ & $4.9 \pm 0.8$ & $6.7 \pm 0.8^{*}$ \\
\hline $\begin{array}{l}\text { The 2nd experimental group }(\mathrm{n}=20) \text {, alcoholization } \\
\text { for } 6 \text { weeks }\end{array}$ & $0.5 \pm 0.4$ & $0.7 \pm 0.4^{\#}$ & $6.4 \pm 0.9^{\#}$ & $7.0 \pm 0.9$ \\
\hline $\begin{array}{l}\text { The 3rd experimental group }(n=20) \text {, alcoholization } \\
\text { for } 16 \text { weeks }\end{array}$ & $0.5 \pm 0.5$ & $0.2 \pm 0.2 @$ & $6.5 \pm 0.6$ & $7.1 \pm 0.7$ \\
\hline The control group $(\mathrm{n}=10)$, after 3,6 and 16 weeks & $2.5 \pm 0.6$ & $1.6 \pm 0.6$ & - & $3.9 \pm 1.1$ \\
\hline
\end{tabular}

Note: * - statistically significant difference ( $p<0.001)$, compared to the parameters of healthy rats; \# - statistically significant difference $(p<0.001)$, compared to the parameters of the 1st group; @ - statistically significant difference $(p<0.001)$, compared to the parameters of the 2nd group. 


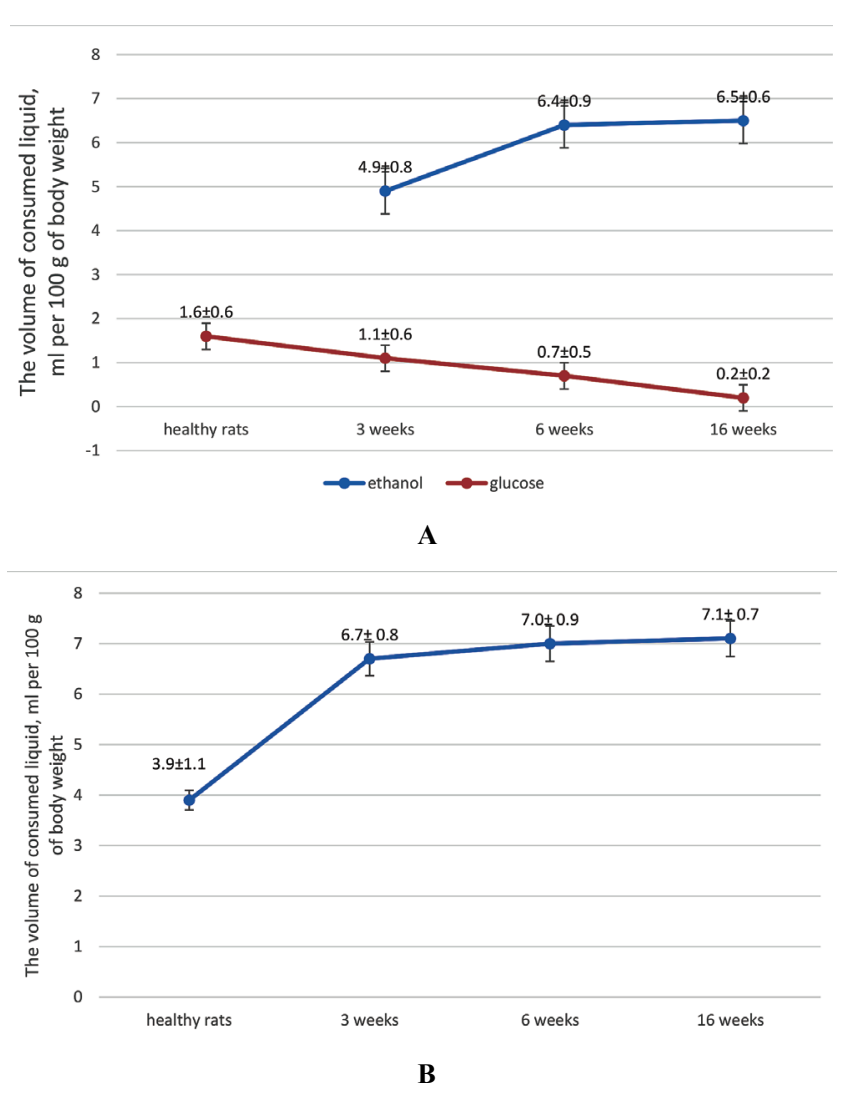

Fig. 1. Dynamics of $5 \%$ glucose and $10 \%$ ethanol solutions consumption (A) and the total volume of consumed liquids (B) at different periods of forced alcoholization.

Horizontal axis includes periods of forced alcoholization: healthy rats before alcoholization; 3 weeks, 6 weeks, and 16 weeks of alcoholization. Vertical axis represents the volumes of consumed alcohol: per $100 \mathrm{~g}$ weight of the animal $(\mathrm{ml} / 100 \mathrm{~g}), \boldsymbol{X} \pm \boldsymbol{s}$.

Observations of glucose consumption have shown that in alcoholized rats, glucose loses its hedonic properties. The conclusion was made due to reduced glucose preference by alcoholized rats, compared to healthy animals. Our results are consistent with the data of other researchers who showed that in rats with a formed alcohol addiction, the preference for alcohol intake did not decrease when there was a free choice between alcohol and pure water sweetened with sugar $[7,13]$. The experiment has revealed that the duration of alcoholization, and, consequently, the degree of alcoholization affect the volume of consumed glucose solution. The longer alcoholization lasted $(3,6$ or 16 weeks), the less volume of glucose solution was consumed by animals under condition of free choice. Table 1 indicates that the level of glucose consumption significantly decreases when comparing the volumes of drunk glucose solutions in different reporting periods. Thus, by the end of the 16th week of alcoholization, under condition of free choice, the glucose consumption is, on average, 8 times lower than that of healthy animals. This dynamic is clearly represented in Figure 1.

So, why has an alcoholized rat stopped enjoying such a delicious glucose? After all, glucose is a favorite delicacy for almost all mammals for the reason that it is probably the only nutrient substrate for brain cells. We suggest that the answer to the question may be a decrease in the functional activity of glycolysis enzymes. According to the general biological principle of feedback loop, a decrease of the substrate level inevitably leads to a decrease in both the activity and the number of enzymes for this substrate. In the absence of glucose, the metabolism of neurons is rearranged to the synthesis of macroergic molecules by the oxidation of ketone bodies. And we assume that as a result of prolonged alcoholization, the brain not only switches its metabolism to nutrition with ketone bodies, but also loses the ability to utilize glucose. That is why, "being unnecessary", glucose loses its hedonic properties for alcoholized animals.

Ethanol stimulates the synthesis of ketone bodies in the liver. The liver biochemistry creates a vicious circle: excess of ethanol leads to hypoglycemia $\rightarrow$ hypoglycemia leads to ketosis $\rightarrow$ ketosis requires ethanol $[1,5,9]$. Ketone bodies become the only stable nutrient for the brain. That is why alcoholized rats probably "require" only ketone bodies and refuse glucose, regardless of the degree of hypoglycemia.

We propose to look at the problem of alcohol addiction in this way: the essence of alcoholism is not a dependence on ethanol, but on ketone bodies.

After the termination of alcoholization, the drinking behavior of the animals was observed for another three weeks. The volume of consumed liquid in all groups and subgroups was different (Tables 2-4). This depended on three factors:

- on the duration of preliminary forced alcoholization;

- on the time elapsed after the end of forced alcoholization;

- on the forced administration of a starch solution per os.

Analyzing of the data in Tables 2-4, we are able to make a number of assumptions.

When comparing the levels of glucose consumption in one reporting period, in the second subgroups of experimental groups 1 and 2, they were significantly less than the same indicators in the first subgroups. It is obviously related to the fact that the rats of the second subgroups were additionally receiving glucose (a starch solution) per os.

Probably, for the same reason, the total consumption of all types of liquids was always lower in animals of the second subgroups.

Water consumption in the same reporting period was always higher in rats of the second subgroups. Obviously, it was caused by the osmotic activity of glucose, added in the form of a starch solution per os.

Under other equal conditions (the same duration of alcoholization, its termination, free access to all types of drinking), the consumption of ethanol in the 
The volumes of consumed liquid by rats in 3 weeks of forced alcoholization of the 1st experimental group, under the condition of free choice

\begin{tabular}{|c|c|c|c|c|c|c|}
\hline \multirow{2}{*}{ Sub-group } & \multirow{2}{*}{ Drinking conditions } & \multirow{2}{*}{$\begin{array}{l}\text { Weeks after the end } \\
\text { of alcoholization }\end{array}$} & \multicolumn{4}{|c|}{ The volume of drunk liquid, ml } \\
\hline & & & Pure water & $5 \%$ glucose & $10 \%$ ethanol & Total volume \\
\hline \multirow{3}{*}{$\begin{array}{c}1 \mathrm{st}, \\
\mathrm{n}=10\end{array}$} & \multirow{3}{*}{$\begin{array}{l}\text { Free choice } \\
\text { and } 0.9 \% \mathrm{NaCl} \\
\text { per os }\end{array}$} & One & $0,6 \pm 0,7$ & $1,1 \pm 0,6$ & $4,9 \pm 0,7$ & $6,6 \pm 0,9$ \\
\hline & & Two & $0,6 \pm 0,5$ & $1,5 \pm 0,5$ & $4,4 \pm 0,4$ & $6,7 \pm 0,6$ \\
\hline & & Three & $1,0 \pm 0,6$ & $1,7 \pm 0,4$ & $3,9 \pm 0,5$ & $6,7 \pm 1,0$ \\
\hline \multirow{3}{*}{$\begin{array}{l}2 \mathrm{nd}, \\
\mathrm{n}=10\end{array}$} & \multirow{3}{*}{$\begin{array}{l}\text { Free choice } \\
\text { and a starch solution } \\
\text { per os }\end{array}$} & One & $2,1 \pm 0,4$ & $0,8 \pm 0,4^{*}$ & $2,1 \pm 0,7^{*}$ & $5,4 \pm 0,8$ \\
\hline & & Two & $2,7 \pm 0,8$ & $0,6 \pm 0,5^{*}$ & $1,2 \pm 0,6^{* \#}$ & $4,5 \pm 0,7^{*}$ \\
\hline & & Three & $3,2 \pm 0,5$ & $0,7 \pm 0,6^{*}$ & $0,6 \pm 0,4 * @$ & $4,5 \pm 0,8^{*}$ \\
\hline
\end{tabular}

Notes for tables 2-4: * statistically significant difference $(p<0.001)$, compared to the parameters of the 1 st group at the same time period; \# - statistically significant difference $(p<0.001)$, compared to the parameters of the 2nd subgroup in one week after alcoholization; @ - statistically significant difference $(p<0.001)$, compared to the parameters of the 2nd subgroup in two weeks after alcoholization.

Table 3

The volumes of consumed liquid by rats in 6 weeks of forced alcoholization of the 2 nd experimental group, under the condition of free choice

\begin{tabular}{|c|c|c|c|c|c|c|}
\hline \multirow[t]{2}{*}{ Sub-group } & \multirow[t]{2}{*}{ Drinking conditions } & \multirow{2}{*}{$\begin{array}{l}\text { Weeks after the end of } \\
\text { alcoholization }\end{array}$} & \multicolumn{4}{|c|}{ The volume of drunk liquid, ml } \\
\hline & & & Pure water & $5 \%$ glucose & $10 \%$ ethanol & Total volume \\
\hline \multirow{3}{*}{$\begin{array}{c}1 \mathrm{st}, \\
\mathrm{n}=10\end{array}$} & \multirow{3}{*}{$\begin{array}{l}\text { Free choice } \\
\text { and } 0.9 \% \mathrm{NaCl} \\
\text { per os }\end{array}$} & One & $0,5 \pm 0,4$ & $0,7 \pm 0,5$ & $6,4 \pm 0,8$ & $7,0 \pm 0,6$ \\
\hline & & Two & $0,8 \pm 0,7$ & $0,5 \pm 0,8$ & $5,9 \pm 0,8$ & $6,5 \pm 1,0$ \\
\hline & & Three & $1,0 \pm 0,7$ & $0,7 \pm 0,7$ & $6,1 \pm 0,5$ & $6,4 \pm 0,8$ \\
\hline \multirow{3}{*}{$\begin{array}{l}\text { 2nd, } \\
\mathrm{n}=10\end{array}$} & \multirow{3}{*}{$\begin{array}{l}\text { Free choice } \\
\text { and a starch solution } \\
\text { per os }\end{array}$} & One & $1,6 \pm 0,5$ & $0,4 \pm 0,6^{*}$ & $3,9 \pm 0,6^{*}$ & $5,6 \pm 0,8^{*}$ \\
\hline & & Two & $1,7 \pm 0,7$ & $0,3 \pm 0,6^{*}$ & $2,1 \pm 0,5^{* \#}$ & $4,3 \pm 0,7^{*}$ \\
\hline & & Three & $2,1 \pm 1,0$ & $0,4 \pm 0,5^{*}$ & $1,9 \pm 0,5 * @$ & $4,4 \pm 0,9^{*}$ \\
\hline
\end{tabular}

The volumes of consumed liquid by rats in 16 weeks of forced alcoholization of the $\mathbf{3 d}$ experimental group, under the condition of free choice

\begin{tabular}{|c|c|c|c|c|c|c|}
\hline \multirow[t]{2}{*}{ Sub-group } & \multirow[t]{2}{*}{ Drinking conditions } & \multirow{2}{*}{$\begin{array}{l}\text { Weeks after the end of } \\
\text { alcoholization }\end{array}$} & \multicolumn{4}{|c|}{ The volume of drunk liquid, ml } \\
\hline & & & Pure water & $5 \%$ glucose & $10 \%$ ethanol & Total volume \\
\hline \multirow{3}{*}{$\begin{array}{c}1 \text { st, } \\
n=10\end{array}$} & \multirow{3}{*}{$\begin{array}{l}\text { Free choice } \\
\text { and } 0.9 \% \mathrm{NaCl} \\
\text { per os }\end{array}$} & One & $0,8 \pm 0,3$ & $0,2 \pm 0,2$ & $6,5 \pm 0,6$ & $7,1 \pm 0,8$ \\
\hline & & Two & $0,9 \pm 0,5$ & $0,2 \pm 0,1$ & $6,3 \pm 0,4$ & $7,0 \pm 0,5$ \\
\hline & & Three & $0,9 \pm 0,4$ & $0,3 \pm 0,1$ & $6,4 \pm 0,5$ & $7,1 \pm 0,7$ \\
\hline \multirow{3}{*}{$\begin{array}{c}2 \mathrm{nd}, \\
\mathrm{n}=10\end{array}$} & \multirow{3}{*}{$\begin{array}{l}\text { Free choice } \\
\text { and a starch solution } \\
\text { per os }\end{array}$} & One & $1,2 \pm 0,6$ & $0,1 \pm 0,1$ & $5,5 \pm 0,6$ & $5,9 \pm 0,8^{*}$ \\
\hline & & Two & $1,4 \pm 0,4$ & $0,1 \pm 0,1$ & $3,1 \pm 0,6^{* \#}$ & $4,9 \pm 0,7^{*}$ \\
\hline & & Three & $1,6 \pm 0,5$ & $0,2 \pm 0,2$ & $2,7 \pm 0,7^{*} @$ & $4,7 \pm 0,9^{*}$ \\
\hline
\end{tabular}

second subgroups decreased to a greater extent than in the first ones within three weeks. Thus, at the second week of metabolic correction of glycemic level (and even at the first week in groups 1 and 2), the level of ethanol consumption in the second subgroups of all experimental groups significantly decreased, compared to the same parameters of the first subgroups (in which the rats did not receive a starch solution).

Moreover, the duration of metabolic correction with a starch solution matters: the longer it is, the less craving for alcohol will be. This can be seen from the dynamics of ethanol consumption within the second subgroups from the first to the third week of observation. By the end of the second week of alimentary correction, the level of ethanol consumption in the second subgroups of all experimental groups decreased $(p<0.001)$, compared to the same indicators in the first week. By the end of the third week, the ethanol consumption was lower than in the second week $(p<0.001)$. 
The obtained data allows us to suggest that the forced excess of glucose in the body (due to alimentary correction of glycemic level) helps to restore the activity of glycolysis enzymes. Under this condition, ketone bodies become "unnecessary". Therefore, there is no need for ethanol as a ketone formation stimulator.

Our conclusion is consistent with studies in which the use of appetite-enhancing drugs led to an increase in food intake and a decrease in alcohol consumption in patients in a state of withdrawal [8]. And additional physical activity (and, consequently, an increase in glycemia - author's note) reduces the risk of relapse of alcohol consumption [12].

From the proposed position, it is quite easy to explain the direct effect of forced alcoholization duration (and, consequently, the degree of alcoholization) on level of glucose consumption (of hedonic significance): the longer alcoholization (3, 6 and 16 weeks) lasts, the less glucose will be consumed by rats under condition of free choice (Fig. 1).

The similar conclusions were drawn by the other researchers. Thus, they state that hedonic stimuli probably act as irritants for the rewarding system only in a healthy brain or in the early stages of addiction formation, but completely lose their significance as stimuli at later stages of addiction [7, 13]. Alcoholized animal models show a decrease in the importance of both vital and behavioral components of life that have hedonic significance [4].

\section{CONCLUSIONS}

Alcohol-dependent rats reject the glucose solution offered as a drink. But prolonged and forced administration of glucose leads to a decrease in alcohol consumption.

\section{REFERENCES}

1. Andersen L.V., Bruun J.M. [Alcoholic ketoacidosis]. Ugeskr Laeger. 2019 Jun 3;181(23):V01190001. [in Danish]. View at: PubMed: https://pubmed.ncbinlm.nih.gov/31267934/ Europe PMC: https://europepmc.org/article/ $\operatorname{med} / 31267934$

2. Edelman E.J., Fiellin D.A. In the Clinic. Alcohol Use. Ann Intern Med. 2016 Jan 5;164(1):ITC1-16. DOI: $10.7326 /$ aitc201601050 View at: Publisher Site: https://www.acpjournals.org/doi/10.7326/ AITC201601050

PubMed: https://pubmed.ncbi.nlm.nih.gov/26747315/

3. Gensburger M., Ghuysen A. [Pharmacotherapy of most severe forms of alcohol withdrawal]. Rev Med Liege. 2019 May;74(5-6):365-372. [in French]. View at: PubMed: https://pubmed.ncbi.nlm.nih. gov/31206282/

Europe PMC: https://europepmc.org/article/ $\operatorname{med} / 31206282$

4. Goltseker K., Hopf F.W., Barak S. Advances in behavioral animal models of alcohol use disorder. Alcohol. 2019 Feb;74:73-82. DOI: 10.1016/j.alcohol.2018.05.014

View at: Publisher Site: https://www. sciencedirect.com/science/article/abs/pii/ S0741832918301046?via\%3Dihub

PubMed: https://pubmed.ncbi.nlm.nih.gov/30424979/

5. Höjer J. [Alcoholic ketoacidosis - a review]. Lakartidningen. 2017 Oct 3;114:EP6D. [in Swedish]. View at: PubMed: https://pubmed.ncbi.nlm.nih. gov/28994854/

Europe PMC: https://europepmc.org/article/ $\mathrm{med} / 28994854$

6. Koenig L.B., Haber J.R., Jacob T. Transitions in alcohol use over time: a survival analysis. BMC Psychol. 2020 Nov 3;8(1):115. DOI: 10.1186/s40359-020-00479-1.

View at: Publisher Site: https://bmcpsychology. biomedcentral.com/articles/10.1186/s40359-020-00479-1 PubMed: https://pubmed.ncbi.nlm.nih.gov/33143748/ Europe PMC: https://europepmc.org/articles/ pmc7607670/bin/40359_2020_479_moesm1_esm.docx

7. Lesscher H.M., Houthuijzen J.M., Koerkamp M.J.G., Holstege F.C.P., Vanderschuren L.J.M.J. Amygdala $14-3-3 \zeta$ as a novel modulator of escalating alcohol intake in mice. PLoS One. 2012; 7(5): e37999. DOI: 10.1371/journal.pone.0037999.

View at: Publisher Site: https://journals.plos.org/ plosone/article?id=10.1371/journal.pone.0037999 PubMed: https://pubmed.ncbi.nlm.nih.gov/22629472/ PubMed Central: https://www.ncbi.nlm.nih.gov/pmc/ articles/PMC3358291/

8. Mansoor K., Qadan F., Hinum A., Schneider C., Hechenbichler K., Schmidt M., Linsinger G., Matalka K. An open prospective pilot study of a herbal combination "Relief" as a supportive dietetic measure during alcohol withdrawal. Neuro Endocrinol Lett. 2018 Mar; 39(1):1-8.

View at: PubMed: https://pubmed.ncbi.nlm.nih. gov/29604618/

Europe PMC: https://europepmc.org/article/ $\operatorname{med} / 29604618$

9. McGuire L.C., Cruickshank A.M., Munro P.T. Alcoholic ketoacidosis. Emerg Med. 2006 Jun; 23(6):417-20. DOI: 10.1136/emj.2004.017590.

View at: PubMed: https://pubmed.ncbi.nlm.nih. gov/16714496/

PubMed Central: http://www.ncbi.nlm.nih.gov/pmc/ articles/pmc2564331/

Europe PMC: https://europepmc.org/article/pmc/ pmc2564331

10. Panova T.I., Bortnikova A.K. Ketosis Level as a Factor Determining Addictive Behavior of Alcoholized Rats. Neurophysiology. 2016; 48(4): 252-258. DOI: 10.1007/ s11062-016-9596-4

View at: Publisher Site: https://link.springer.com/ article/10.1007/s11062-016-9596-4

11. [Psychiatry and narcology / Edited by Professor OK Napreyenko / Kyiv: Medicine, 2017: 211-222. [in Ukrainian]. 
View at: MedPublish: https://www.medpublish.com. ua/psihiatrija-i-narkologija-pidruchnik-vnz-v-r-a-gtsonnik-ok-napryeyenko-am-skripnikov-ta-in-za-redok-napryeyenka-3ye-vid-vipr/p-705.html?language $=$ ru

12. Thompson T.P., Taylor A.H., Wanner A., Husk K., Wei Y., Creanor S., Kandiyali R., Neale J., Sinclair J., Nasser M., Wallace G. Physical activity and the prevention, reduction, and treatment of alcohol and/or substance use across the lifespan (The PHASE review): protocol for a systematic review. Syst Rev. 2018 Jan 22;7(1):9. DOI: $10.1186 / \mathrm{s} 13643-018-0674-0$

View at: Publisher Site: https://systematicreviewsjournal. biomedcentral.com/articles/10.1186/s13643-018-0674-0 PubMed: https://pubmed.ncbi.nlm.nih.gov/29357931/ PubMed Central: https://www.ncbi.nlm.nih.gov/pmc/ articles/PMC5778642/

13. Vendruscolo L.F., Barbier E., Schlosburg J.E., Misra K.K., Whitfield T.W., Logrip M.L., Rivier C., RepunteCanonigo V., Zorrilla E.P., Sanna P.P., Heilig M., Koob G.F. Corticosteroid-dependent plasticity mediates compulsive alcohol drinking in rats. J. Neurosci.
2012; 32(22): 7563-71. DOI: 10.1523\%2FJNEUROS CI.0069-12.2012

View at: Publisher Site: https://www.jneurosci.org/ content $/ 32 / 22 / 7563$

PubMed: https://pubmed.ncbi.nlm.nih.gov/22649234/ PubMed Central: https:/www.ncbi.nlm.nih.gov/pmc/ articles/PMC3375621/

14. Yokoyama A., Yokoyama T., Mizukami T., Matsui T., Shiraishi K., Kimura M., Matsushita S., Higuchi S., Maruyama K. Alcoholic Ketosis: Prevalence, Determinants, and Ketohepatitis in Japanese Alcoholic Men. Alcohol Alcohol. 2014 Nov; 49(6):618-25. DOI: 10.1093/alcalc/agu048.

View at: Publisher Site: https://academic.oup.com/ alcalc/article/49/6/618/2888130

PubMed: https://pubmed.ncbi.nlm.nih.gov/25085997/ Published: 31.03 .2021

\title{
ПИТНА ТА ГЕДОНІЧНА ПОВЕДІНКА АЛКОГОЛІЗОВАНИХ ЩУРІВ
}

\author{
${ }^{1}$ Панова Т.І., ${ }^{2}$ Бортнікова А.К., ${ }^{1}$ Міроненко О.I. \\ ${ }^{1}$ Національний медичний університет імені О.О. Богомольия, Київ, Україна \\ 2 Донецький національний медичний університет імені М. Горького, Украйна \\ panova10000@gmail.com
}

Актуальність. Для купірування алкогольного абстинентного синдрому застосовують внутрішньовенну інфузію глюкози $\mathrm{i}$ антидоти, що нейтралізують кетонові тіла. Але після лікування все одно зберігається потяг до алкоголю, і рецидиви вживання алкоголю спостерігаються у 60-90\% хворих. Залишається нез'ясованим питання, чи існує зв'язок між гіпоглікемією, кетозом, 3 одного боку, і потягом до алкоголю, з іншого.

Мета: 3'ясувати, як впливає на споживання етанолу у алкоголізованих щурів усунення гіпоглікемії і тривале підтримання глікемії на рівні норми. При цьому ми вибрали два альтернативні способи усунення гіпоглікемії: 1) надання тваринам вільного необмеженого доступу до поїлки з глюкозою; 2) примусове посилене вуглеводне харчування.

Матеріали та методи. 70 щурів містили по одному в клітці. На першому етапі, протягом одного тижня, в кожну клітину були поміщені по дві поїлки - 3 чистою водою і 5\% глюкозою. На другому етапі проводили примусову алкоголізацію: в кожній клітині була тільки одна поїлка - $310 \%$ етанолом. Терміни алкоголізації були різними: для щурів 1-ї групи $(\mathrm{n}=20)-3$ тижні, $2-1$ групи $(\mathrm{n}=20)-6$ тижнів, 3-ї групи $(\mathrm{n}=20)-16$ тижнів. Тварини контрольної групи $(\mathrm{n}=10)$ в якості пиття отримували воду. На третьому етапі, після закінчення примусової алкоголізації, у тварин протягом трьох тижнів був вільний вибір між водою, $5 \%$ глюкозою, 10\% етанолом, а у контрольних щурів - вибір між водою і 5\% глюкозою. На третьому етапі кожну з експериментальних груп розділили на дві підгрупи: по 10 особин у кожній підгрупі. Тварин других підгруп містили на посиленому вуглеводному харчуванні: 3 рази на день per os вводили 1 мл 40\% крохмального киселю (в перерахунку на глюкозу - це 2,0 г / кг). Протягом усього експерименту щодня реєстрували кількість випитого пиття всіх видів. При обробці результатів використовували пакет MedStat.

Результати. Здорові щури щодня випивали води по 2,5 \pm 0,6 мл / 100 г ваги, і глюкози - по 1,6 0 0,6 мл / 100 г ваги. У перші 7 днів примусової алкоголізації тварини випивали алкоголю по $3,1 \pm 0,7$ мл / 100 г ваги. До кінця 3 тижня кількість споживаного етанолу зросла $(\mathrm{p}<0,001)$ до 4,9 $\pm 0,8$ мл / 100г ваги, що свідчить про адаптацію. До кінця 6 тижні стався «стрибок» споживання розчину етанолу - до $6,4 \pm 0,9$ мл / 100 г ваги тварини. Кількість випитого, в порівнянні з показниками на 3 тижні, зросла в 1,3 рази $(\mathrm{p}<0,001)$. Споживання алкоголю на 6 тижні було «стелею», оскільки подальше подовження терміну алкоголізації (аж до 16 тижня) змін в питному поведінці не спричинило $(\mathrm{p}=0,712)$. Вважаємо, що 6 тижнів - це мінімальний термін примусової алкоголізації. В процесі алкоголізації, щодобове загальне споживання пиття в порівнянні зі здоровими щурами збільшувалася, і до кінця 16 тижня перевищило показники здорових тварин в 1,8 рази. У алкоголізованих щурів глюкоза втрачає свої гедонічні властивості. До кінця 16 тижня алкоголізації споживання глюкози в умовах вільного вибору у 8 разів нижче, ніж у здорових тварин. Щури, які отримували додаткове посилене вуглеводне харчування, споживали етанолу менше. Тривалість метаболічної корекції розчином крохмалю має значення: чим вона триваліша, тим менше потяг до алкоголю. 
Висновки. Алкоголізовані щури відкидають запропоновану в питво глюкозу. Але тривале примусове введення глюкози сприяє зменшенню споживання етанолу.

Ключові слова: алкоголізовані щури, гіпоглікемія, втрата гедонічних властивостей глюкози, примусова корекція глікемії.

\title{
ПИТЬЕВОЕ И ГЕДОНИЧЕСКОЕ ПОВЕДЕНИЕ АЛКОГОЛИЗИРОВАННЫХ КРЫС
}

\author{
${ }^{1}$ Панова Т.И., ${ }^{2}$ Бортникова А.К., ${ }^{1}$ Мироненко О.И. \\ ${ }^{1}$ Национальный медичинский университет имени А.А. Богомольциа, Украина \\ ${ }^{2}$ Донецкий национальный медицинский университет имени М. Горького, Украина \\ panova10000@gmail.com
}

Актуальность. Для купирования алкогольного абстинентного синдрома применяют внутривенную инфузию глюкозы и антидоты, нейтрализующие кетоновые тела. Но после лечения всё равно сохраняется влечение к алкоголю, а рецидивы употребления алкоголя наблюдаются у 60-90 \% больных. Остаётся невыясненным вопрос, существует ли связь между гипогликемией, кетозом, с одной стороны, и влечением к алкоголю, с другой.

Цель: выяснить, как влияет на потребление этанола у алкоголизированных крыс устранение гипогликемии и длительное поддержание гликемии на уровне нормы. При этом мы выбрали два альтернативных способа устранения гипогликемии: 1) предоставление животным свободного неограниченного доступа к поилке с глюкозой; 2) принудительное усиленное углеводное питание.

Материалы и методы. 70 крыс содержали по одной в клетке. На первом этапе, в течение одной недели, в каждую клетку были помещены по две поилки - с чистой водой и 5 \% глюкозой. На втором этапе проводили принудительную алкоголизацию: в каждой клетке была только одна поилка - с 10 \% этанолом. Сроки алкоголизации были разными. Для крыс 1-й группы (n=20) -3 недели, 2-й группы $(\mathrm{n}=20)-6$ недель, 3-й группы $(\mathrm{n}=20)-16$ недель. Животные контрольной группы $(\mathrm{n}=10)$ в качестве питья получали воду. На третьем этапе, после окончания принудительной алкоголизации, у животных в течение трёх недель был свободный выбор между водой, 5\% глюкозой, $10 \%$ этанолом. А у контрольных крыс - выбор между водой и 5 \% глюкозой. На третьем этапе каждую из экспериментальных групп разделили на две подгруппы: по 10 особей в каждой подгруппе. Животных вторых подгрупп содержали на усиленном углеводном питании: 3 раза в день per os вводили 1 мл $40 \%$ крахмального киселя (в пересчёте на глюкозу - это 2,0 г/кг). На протяжение всего эксперимента ежедневно регистрировали количество выпитого питья всех видов. При обработке результатов использовали пакет MedStat.

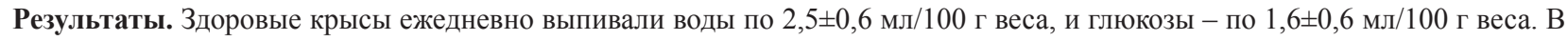
первые 7 дней принудительной алкоголизации животные выпивали алкоголя по $3,1 \pm 0,7$ мл/100 г веса. К концу 3 недели количество потребляемого этанола возросло $(\mathrm{p}<0,001)$ до $4,9 \pm 0,8$ мл/100г веса, что свидетельствует об адаптации. К концу 6 недели произошел «скачок» потребления раствора этанола - до 6,4 0 ,9мл/100 г веса животного. Количество выпитого, по сравнению с показателями на 3 неделе, возросло в 1,3 раза $(\mathrm{p}<0,001)$. Потребление алкоголя на 6 неделе было «потолком», поскольку дальнейшее удлинение срока алкоголизации (вплоть до 16 недели) изменений в питьевом поведении не повлекло (p=0,712). Полагаем, что 6 недель - это минимальный срок принудительной алкоголизации. В процессе алкоголизации, ежесуточное общее потребление питья по сравнению со здоровыми крысами увеличивалось, и к концу 16 недели превысило показатели здоровых животных в 1,8 раза. У алкоголизированных крыс глюкоза утрачивает свои гедонические свойства. К концу 16 недели алкоголизации потребление глюкозы в условиях свободного выбора в 8 раз ниже, чем у здоровых животных. Крысы, получавшие дополнительное усиленное углеводное питание, потребляли этанола меньше. Продолжительность метаболической коррекции раствором крахмала имеет значение: чем она длительнее, тем меньше влечение к алкоголю.

Выводы. Алкоголизированные крысы отвергают предлагаемую в питье глюкозу. Но продолжительное принудительное введение глюкозы способствует уменьшению потребления этанола.

Ключевые слова: алкоголизированные крысы, гипогликемия, утрата гедонических свойств глюкозы, принудительная коррекция гликемии. 